\title{
Interspecific and geographical variation in the sequence of rDNA expansion segment D3 of Ixodes ticks (Acari: Ixodidae)
}

\author{
DENSON KELLY MCLAIN*, JING LI \& JAMES H. OLIVER, JR \\ Biology Department, PO Box 8042, Georgia Southern University, Statesboro, Georgia 30460, U.S.A.
}

\begin{abstract}
The base sequence of the rDNA D3 expansion segment and flanking H14 stem varies between six species of Ixodes ticks (Acari: Ixodidae) where only 33 invariant sites occur among sequences of 123-203 bases in length. Multiple copies of $D 3$ were sequenced from localities across the geographical ranges of four species to investigate deep population genetic structure. Two species, I. pacificus, from western North America, and I. ricinus, from Europe, have no sequence variation indicating a lack of deep genetic structure. One species, I. scapularis, from eastern North America has two forms of the D3 sequence that are distributed differently among northern vs. southern populations, suggesting recent divergence and hybridization. I. persulcatus, from Eurasia, has sequence variation between localities of the order of that observed between other species, suggesting a long history of population isolation and deep genetic structure. With the exception of I. scapularis, sequence variation was not observed within localities. This indicates that cellular processes underpinning concerted evolution have homogenized populations and species for particular rDNA sequence variants.
\end{abstract}

Keywords: concerted evolution, D3, expansion segment, genetic structure, rDNA, tick.

\section{Introduction}

The population genetic structure of a species is the geographical distribution of its component demes and is inferred from both the spatial scale at which genotypes are observed to change and the evolutionary rates of the loci examined (Slatkin, 1987). Population genetic structure is deep if both slowly and rapidly evolving loci exhibit spatial variation and shallow if only rapidly evolving loci exhibit isolation by distance. Population genetic structure reflects historical events such as bottlenecks, colonizations, and range expansions and it reflects also the spatial scale at which the cohesive effect of gene flow is countered by microevolutionary forces promoting genetic divergence (Thompson, 1999). Gene flow rates are determined by habitat continuity, vagility of the species, and barriers to dispersal (Slatkin, 1987).

The population genetic structure of parasites may depend on host habitat preferences and host mobility (Mulvey et al., 1991). Ticks (Acari) are ectoparasites of extremely limited intrinsic vagility (Adeyeye \& Butler, 1989). Consequently, population genetic structure varies according to the host species utilized (Lampo et al.,

*Correspondence. E-mail: dk_mclain@gsvms2.cc.gasou.edu
1998). In general, however, ticks exhibit shallow population genetic structure (Bull et al., 1984).

In the present study, we examine population genetic structuring in four widespread species of hard ticks (Ixodidae): Ixodes pacificus (from western North America), I. persulcatus (from eastern Europe and Asia), I. ricinus (from Europe, western Asia, and northern Africa), and I. scapularis (from eastern North America) (Dennis et al., 1998). As members of the I. ricinus complex, all are competent vectors of human diseases such as spirochaete-mediated Lyme disease (Lane et al., 1991). By including several species in our analysis, we may be able to determine if there is a general pattern for tick genetic structure. A pattern would concomitantly suggest similar rates and mechanisms of gene flow and similar potential to vector disease agents across geographical ranges.

Prior studies employing rapidly evolving genetic markers have revealed shallow genetic structure in Ixodes ticks (Norris et al., 1996; Kain et al., 1999). We have chosen to use rDNA sequence data which could reveal deep genetic structure. Eukaryotic rDNA consists of arrays of a unit containing spacers and associated rRNA genes (Hillis \& Dixon, 1991). The rate of sequence evolution varies across a repeating unit and even within a gene (Hillis \& Dixon, 1991). This permits 
the selection of particular sequences as markers for a desired level of phylogeographic resolution.

The eukaryote 28S rRNA gene is homologous to the prokaryote $23 \mathrm{~S}$ rRNA gene except for the presence of about a dozen expansion segments ranging in length from 10 to several hundred base pairs (Hancock \& Dover, 1988; Hancock et al., 1988). Expansion segments evolve at up to 10 times the rate of the gene core (Kuzoff et al., 1998).

Therefore, we chose to examine sequence variation in the approximately 150-base pair, AT-rich (usually) D3 expansion segment which lies between highly conserved core sequences (Hancock \& Dover, 1988). D3 exhibits substantial intraspecific and interspecific sequence variation (Litvaitis et al., 1994) which is phylogenetically informative and useful for the study of population structure (Kuzoff et al., 1998). Between the conserved core sequences and each side of D3 are 14 relatively nonconserved bases that together correspond to a stem, $H 14$, in the folded transcript. These flanking sequences are also included in our analyses.

We also compare intraspecific sequence variation to interspecific variation among these and two other accessible species: I. woodi, which is widely distributed in North America west of the Mississippi River (Robbins \& Keirans, 1992), and I. affinis (also a member of the I. ricinus complex) which occurs in Central America and south-eastern North America (Oliver et al., 1987).

\section{Materials and methods}

\section{Sources of ticks}

Fertilized tick eggs, larvae, or adults were provided from field collections or laboratory stocks as indicated in Table 1. Live tissue samples were placed in isopropanol prior to shipping. Subsequently, samples were stored at $-70^{\circ} \mathrm{C}$ until DNA was extracted. Species were represented by the following number of geographical samples: one for Ixodes affinis, three for I. pacificus, eight for I. persulcatus, six for I. ricinus, 10 for I. scapularis, and one for I. woodi. For each locality of each species, a single DNA extraction was performed on the entire (pooled) sample as listed in Table 1.

\section{DNA extraction and PCR amplification}

DNA was isolated using the procedure of Livak (1984) which entailed grinding tissues with plastic pestles in a lysis buffer of SDS that contained EDTA to chelate proteins. Enzymes in the slurry were heat denatured then precipitated on ice after addition of potassium acetate. Following centrifugation, the supernatant was retained and ethanol precipitated to recover nucleic acids. One-2500th of each resulting $10 \mu \mathrm{g}$ recovery of DNA was used to amplify rDNA D3. PCR amplification employed a Perkin Elmer DNA thermal cycler and Perkin Elmer GeneAmp reagents (Perkin Elmer Corporation, Norwalk, CT). DNA was amplified in a $100-\mu \mathrm{L}$ volume for 37 cycles. The first cycle consisted of $1 \mathrm{~min}$ for denaturation at $97^{\circ} \mathrm{C}, 2 \mathrm{~min}$ for annealing at $37^{\circ} \mathrm{C}$, and $2 \mathrm{~min}$ for extension at $72^{\circ} \mathrm{C}$. The next 35 cycles were the same except that denaturation was at $94^{\circ} \mathrm{C}$. The last cycle was the same as the middle 35 cycles except that extension was permitted for $10 \mathrm{~min}$. Amplification primers were: (1) 5' GT GAATTC ACCCGTCTTGAAACAC 3' with the 6-base EcoRI recognition sequence ending at base 8 and a conserved $28 \mathrm{~S}$ sequence running from primer bases $9-25$ (= bases $4045-4060$ in Tautz et al. [1988]) and (2) 5' GT GGATCC TGAGGGAAACTTCGG 3' with the 6-base BamHI recognition sequence ending at base 8 and a conserved $28 \mathrm{~S}$ sequence running from primer bases 9-23 (= bases $4424-4410$ in Tautz et al. [1988]). The $3^{\prime}$ end of the primers represent conserved core sequences that flank the D3 expansion segment in Drosophila melanogaster (Tautz et al., 1988).

PCR products and the plasmid pBluescript II (Stratagene Cloning Systems, La Jolla, CA) were digested with both EcoRI and BamHI, ethanol-precipitated, resuspended in water, and ligated. Escherichia coli strain XL1-Blue (Stratagene) was transformed with the ligation products using the $\mathrm{CaCl}_{2}$ procedure and ampicillin selection (Sambrook et al., 1989).

\section{DNA sequencing and analysis}

Four subclones were sequenced from almost all sites from which a sample of a tick species was received. Two exceptions were I. persulcatus from Hokkaido Island (Japan) and Inner Mongolia (China) where only one subclone was sequenced from each site. Double-strand inserts in pBluescript II were sequenced by the dideoxy chain-termination method using Sequenase reagent kits (U.S. Biochemical Corporation, Cleveland, OH). Inserts were sequenced in both forward and reverse directions. When compressions were suspected, sequencing reactions were repeated using dITP. Sequencing reaction products were separated in a $6 \%$ acrylamide/urea gel for which the top and bottom buffers were $1 \times$ TBE (Sambrook et al., 1989). GenBank/EMBL accession numbers for sequences are provided in Table 1.

Sequence alignment was accomplished with GENETIC DAta environment (Smith et al., 1994). Phylogenetic analyses using the criteria of maximum likelihood and maximum parsimony were conducted with PAUP version 4.0b3 (Swofford, 2000). The neighbour-joining method (Saitou \& Nei, 1987) was also used to assess 
Table 1 Sources of ticks, nature of tissues used for PCR amplification, and GenBank/EMBL accession numbers for associated DNA sequences

\begin{tabular}{|c|c|c|c|}
\hline Species and access no. & Locality & Tissue type & Collector \\
\hline $\begin{array}{l}\text { Ixodes affinis } \\
\text { AF303991 }\end{array}$ & $\begin{array}{l}\text { South-eastern U.S.A. } \\
\text { (Georgia) }\end{array}$ & $\begin{array}{l}3 \text { adult males and } \\
3 \text { adult females }\end{array}$ & $\begin{array}{l}\text { J. Hutcheson, } \\
\text { Ft. Collins, CO }\end{array}$ \\
\hline $\begin{array}{l}\text { Ixodes pacificus } \\
\text { AF303989 } \\
\text { AF303989 }\end{array}$ & $\begin{array}{l}\text { South-western U.S.A. } \\
\text { (Arizona) } \\
\text { Western U.S.A. } \\
\text { (2 sites: California) }\end{array}$ & $\begin{array}{l}3 \text { adult males and } \\
3 \text { adult females } \\
\text { Eggs of } 6 \text { females } \\
\text { of a laboratory colony } \\
\text { (established in 1992) }\end{array}$ & $\begin{array}{l}\text { J. M. C. Ribeiro, } \\
\text { Tucson, AZ } \\
\text { J. H. Oliver, Jr., } \\
\text { Statesboro, GA }\end{array}$ \\
\hline $\begin{array}{l}\text { Ixodes persulcatus } \\
\text { AF303994 } \\
\text { AF303992 }\end{array}$ & $\begin{array}{l}\text { Central Russia } \\
\text { (Altai Mountains) } \\
\text { Western Russia } \\
\text { (near St. Petersburg) }\end{array}$ & $\begin{array}{l}\text { Eggs of } 5 \text { field- } \\
\text { collected females } \\
\text { Eggs of } 9 \text { field- } \\
\text { collected females }\end{array}$ & $\begin{array}{l}\text { E. Korenberg, } \\
\text { Moscow } \\
\text { E. Korenberg, } \\
\text { Moscow }\end{array}$ \\
\hline AF303993 & $\begin{array}{l}\text { Western Russia } \\
\text { (near Moscow) }\end{array}$ & $\begin{array}{l}3 \text { adult males and } \\
3 \text { adult females }\end{array}$ & $\begin{array}{l}\text { N. A. Filippova, } \\
\text { St. Petersburg }\end{array}$ \\
\hline AF303995 & $\begin{array}{l}\text { Eastern Russia } \\
\text { (Sakhalin Island) }\end{array}$ & $\begin{array}{l}\text { Eggs of } 16 \text { field- } \\
\text { collected females }\end{array}$ & $\begin{array}{l}\text { E. Korenberg, } \\
\text { Moscow }\end{array}$ \\
\hline AF303997 & Dagestan & $\begin{array}{l}3 \text { adult males and } \\
3 \text { adult females }\end{array}$ & $\begin{array}{l}\text { N. A. Filippova, } \\
\text { St. Petersburg }\end{array}$ \\
\hline AF303999 & $\begin{array}{l}\text { Central China } \\
\text { (Heilongjiang) }\end{array}$ & $\begin{array}{l}\text { Larvae from eggs of } \\
\text { field-collected females }\end{array}$ & $\begin{array}{l}\text { Ai Cheng Xu, } \\
\text { Beijing }\end{array}$ \\
\hline AF303998 & $\begin{array}{l}\text { Northern China } \\
\text { (Inner Mongolia) }\end{array}$ & $\begin{array}{l}\text { Eggs of } 3 \text { field- } \\
\text { collected females }\end{array}$ & $\begin{array}{l}\text { Dou Gui-lan, } \\
\text { Beijing }\end{array}$ \\
\hline AF303996 & $\begin{array}{l}\text { Northern Japan } \\
\text { (Hokkaido) }\end{array}$ & $\begin{array}{l}\text { Eggs of a field- } \\
\text { collected female }\end{array}$ & $\begin{array}{l}\text { K. Miyamoto, } \\
\text { Asahikawa }\end{array}$ \\
\hline $\begin{array}{l}\text { Ixodes ricinus } \\
\text { AF303988 }\end{array}$ & $\begin{array}{l}\text { Czechoslovakia } \\
\text { (Bratislava) }\end{array}$ & $\begin{array}{l}\text { Eggs of } 5 \text { field- } \\
\text { collected females }\end{array}$ & $\begin{array}{l}\text { M. Labuda and } \\
\text { F. Ciampor, } \\
\text { Bratislava }\end{array}$ \\
\hline AF303988 & $\begin{array}{l}\text { Ireland } \\
\text { (County Wicklow) }\end{array}$ & $\begin{array}{l}\text { Eggs of a field- } \\
\text { collected female }\end{array}$ & $\begin{array}{l}\text { J. Gray, } \\
\text { Dublin }\end{array}$ \\
\hline AF303988 & $\begin{array}{l}\text { Eastern Rumania } \\
\text { (Moldova) }\end{array}$ & $\begin{array}{l}3 \text { adult males and } \\
3 \text { adult females }\end{array}$ & $\begin{array}{l}\text { E. Korenberg, } \\
\text { Moscow }\end{array}$ \\
\hline AF303988 & $\begin{array}{l}\text { Western Russia } \\
\text { (Pskov region) }\end{array}$ & $\begin{array}{l}\text { Eggs of } 3 \text { field- } \\
\text { collected females }\end{array}$ & $\begin{array}{l}\text { N. A. Filippova, } \\
\text { St. Petersburg }\end{array}$ \\
\hline AF303988 & $\begin{array}{l}\text { Switzerland } \\
\text { (Neuchâtel) }\end{array}$ & $\begin{array}{l}\text { Eggs of a field- } \\
\text { collected female }\end{array}$ & $\begin{array}{l}\text { L. Gern, } \\
\text { Neuchâtel }\end{array}$ \\
\hline AF303988 & $\begin{array}{l}\text { Thetford Forest } \\
\text { (Norfolk, England) }\end{array}$ & $\begin{array}{l}3 \text { adult males and } \\
3 \text { adult females }\end{array}$ & $\begin{array}{l}\text { P. Nuttall, } \\
\text { Oxford }\end{array}$ \\
\hline $\begin{array}{l}\text { Ixodes scapularis } \\
\text { AF303986 } \\
\text { AF303987 }\end{array}$ & $\begin{array}{l}\text { Mid-eastern U.S.A. } \\
\text { (2 sites: Maryland } \\
\text { and North Carolina) }\end{array}$ & $\begin{array}{l}\text { Nymphs of laboratory } \\
\text { colonies (established } \\
\text { in 1992) }\end{array}$ & $\begin{array}{l}\text { J. Piesman, } \\
\text { Ft. Collins, CO }\end{array}$ \\
\hline AF303987 & $\begin{array}{l}\text { Mid-western U.S.A. } \\
\text { (2 sites: Minnesota } \\
\text { and Illinois) }\end{array}$ & $\begin{array}{l}3 \text { adult males and } 3 \\
\text { adult females from each }\end{array}$ & $\begin{array}{l}\text { J. Hutcheson, } \\
\text { Ft. Collins, CO }\end{array}$ \\
\hline AF303987 & $\begin{array}{l}\text { North-eastern U.S.A. } \\
\text { ( } 3 \text { sites: Massachu- } \\
\text { setts, New Jersey, } \\
\text { and New York) }\end{array}$ & $\begin{array}{l}\text { Nymphs of laboratory } \\
\text { colonies (established in } \\
1985,1992, \text { respectively) }\end{array}$ & $\begin{array}{l}\text { J. H. Oliver, Jr., } \\
\text { Statesboro, GA } \\
\text { and J. Piesman, } \\
\text { Ft. Collins, CO }\end{array}$ \\
\hline $\begin{array}{l}\text { AF303986 } \\
\text { AF303987 }\end{array}$ & $\begin{array}{l}\text { South-eastern U.S.A. } \\
\text { ( } 3 \text { sites: barrier islands } \\
\text { off Georgia and Florida) }\end{array}$ & $\begin{array}{l}3 \text { adult males and } 3 \\
\text { adult females from each }\end{array}$ & $\begin{array}{l}\text { J. Hutcheson, } \\
\text { Ft. Collins, CO }\end{array}$ \\
\hline $\begin{array}{l}\text { Ixodes woodi } \\
\text { AF303990 }\end{array}$ & $\begin{array}{l}\text { Central U.S.A. } \\
\text { (Oklahoma) }\end{array}$ & $\begin{array}{l}3 \text { adult males and } \\
3 \text { adult females }\end{array}$ & $\begin{array}{l}\text { C. Hopla, } \\
\text { Norman, OK }\end{array}$ \\
\hline
\end{tabular}


phylogenetic relationships. Genetic distances, $d$, were calculated using the method of Tamura (1992) which is less likely to underestimate $d$ when $d$ is small and when there are transition-transversion or base-composition biases.

To verify that $D 3$ and the supporting stem, $H 14$, were subcloned, sequences flanking the putative expansion segment were compared to those of the D3-flanking, highly conserved core region of the rDNA $28 \mathrm{~S}$ gene of Drosophila melanogaster (Tautz et al., 1988). Flanking sequences of Ixodes species matched those of Drosophila melanogaster except for two base substitutions (5' ACCGTCTTGAAACACGGACCAAGGAG... CCCGAAAGATA $_{\mathrm{T}}$ GGTGAACTATG $_{\mathrm{A}}$ 3', where subscripts indicate substitutions in $D$. melanogaster for the preceding base in ticks). The similarity confirmed the presence of H14 and D3 in Ixodes spp. subclones.

\section{Results}

\section{Intraspecific variation: within populations}

Sequence variation was not observed within localities of I. pacificus (three sites), I. persulcatus (eight sites), I. ricinus (six sites), I. woodi (one site), and I. affinis (one site). However, most I. scapularis sites from the south-eastern and mid-eastern U.S. had the same two sequence variants. To distinguish these, one is referred to as the scapularis form and the other as the dammini form (reflecting an I. scapularis clade formerly described as the separate species, I. dammini [see Rich et al., 1995]). The scapularis form predominated in the southeastern U.S. $(2 / 4,3 / 4$ and $4 / 4$ of sequences from three sites). In the mid-eastern U.S., the scapularis form was less common (1/2 and 2/4 of sequences from two sites).

Scapularis (190 bp) and dammini (188 bp) forms matched at $89 \%$ of their bases in the alignment that included $D 3$ and flanking $\mathrm{H} 14$ sequences of all species. Transversions $(N=14)$ distinguished the sequences more than did transitions $(N=5)$ and insertions/deletions (=indels; $N=5$ ) (Table 2).

\section{Intraspecific variation: between populations}

No sequence variation was observed between localities for either I. pacificus (three sites, 12 sequences) or I. ricinus (six sites, 24 sequences). For I. scapularis, between-localities variation consisted only of differences in the frequencies of scapularis and dammini forms of the sequence (see above). The dammini form was present at all collection sites $(N=10)$ except for one in the southeastern U.S. (Florida). In contrast, the scapularis form was not present in any of the northeastern or midwestern U.S. sites (five sites, 20 sequences). The
Table 2 Nature of sequence variation in Ixodes as a function of the level of comparison

\begin{tabular}{lccc}
\hline & \multicolumn{2}{c}{ Within species } & \\
\cline { 2 - 3 } & $\begin{array}{c}\text { Within } \\
\text { population* }\end{array}$ & $\begin{array}{c}\text { Between } \\
\text { populations } \dagger\end{array}$ & $\begin{array}{c}\text { Between } \\
\text { species }\end{array}$ \\
\hline No. transitions & 4 & 37 & 39 \\
No. transversions & 12 & 54 & 34 \\
No. indels of length & & & \\
1 & 3 & 17 & 27 \\
2 & 0 & 10 & 13 \\
3 & 0 & 2 & 5 \\
4 & 0 & 1 & 4 \\
5 & 0 & 2 & 2 \\
6 & 0 & 0 & 2 \\
7 & 0 & 0 & 1 \\
$>10$ & 0 & 0 & 1 \\
\hline
\end{tabular}

* I. scapularis: dammini vs. scapularis forms.

$\dagger$ I. persulcatus localities.

frequency of scapularis and dammini forms varied significantly among geographical regions (KruskalWallis test, $\chi_{3}^{2}=8.46, P=0.037$ ).

Extensive sequence variation occurred among eight I. persulcatus sites (26 subclones). The two sites in western Russia (Moscow, St. Petersburg) had identical sequences and varied from a south-central Russian site (Altai Mountains) by a single base. All other comparisons among sites were as different in base sequence as comparisons among different species (Fig. 1). Overall, there was a small but significant correlation between genetic and geographical distance (log-transformed) $\left(r=0.40, F_{1,26}=4.92, P=0.036\right.$; Table 3$)$.

Alignment of sequences of all $I$. persulcatus populations (branch A of Fig. 1) resulted in an average level of sequence identity (base matching) of $81 \%$. Sequence variation among $I$. persulcatus localities was almost equally due to base substitutions $(N=82)$ and indels $(N=65)$. The indels ranged from one to six bases in length and accounted for 96 base insertions or deletions (Table 2). Among base substitutions, transversions $(N=50)$ were significantly more common than transitions $\left(N=32 ; \chi_{1}^{2}=3.95, P=0.045\right)$. Indels of only $1-2$ bases were eight times as common as those of three or more bases (Table 2).

\section{Extent of interspecific variation}

The low degree of sequence variation observed within species (excepting I. persulcatus) contrasted with moderate to high levels of interspecific variation (Fig. 1). This variation yielded the same phylogenetic arrangement of D3 sequences with both neighbour-joining 


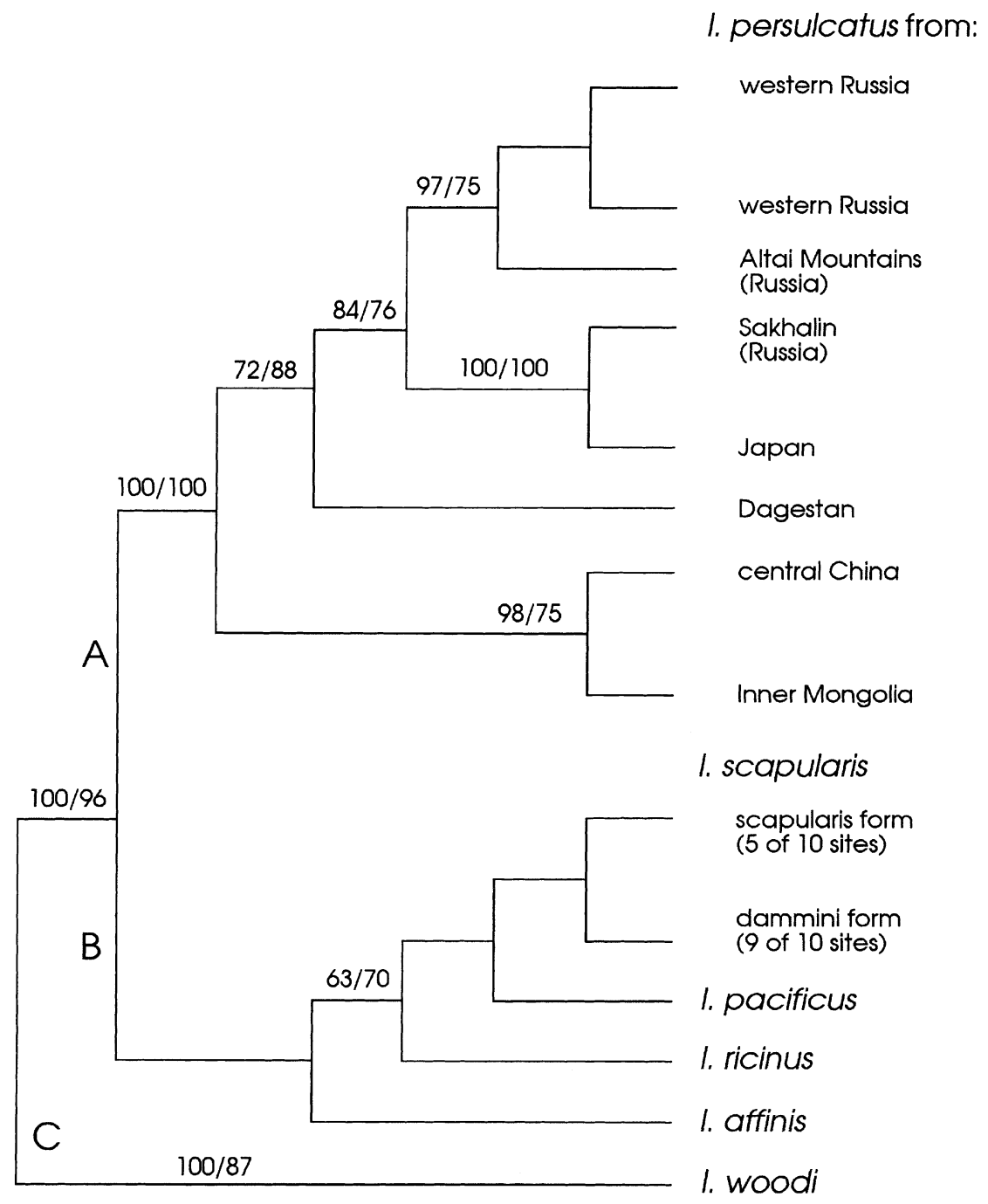

Fig. 1 Maximum parsimony phylogeny of Ixodes populations with percentage support for major features based on maximum likelihood (lower number) and maximum parsimony (upper number).

Table 3 Genetic and geographical distances separating Ixodes persulcatus populations

\begin{tabular}{lcccccccc}
\hline & $\begin{array}{c}\text { Russia } \\
\text { St. P. }\end{array}$ & $\begin{array}{c}\text { Russia } \\
\text { Moscow }\end{array}$ & $\begin{array}{c}\text { Altai } \\
\text { Mtns. }\end{array}$ & Sakhalin & Japan & Dagestan & $\begin{array}{c}\text { Central } \\
\text { China }\end{array}$ & $\begin{array}{c}\text { Inner } \\
\text { Mongolia }\end{array}$ \\
\hline $\begin{array}{l}\text { Russia } \\
\quad \text { St. P. }\end{array}$ & - & 0 & 0.008 & 0.172 & 0.094 & 0.074 & 0.178 & 0.177 \\
$\begin{array}{l}\text { Russia } \\
\quad \text { Moscow }\end{array}$ & 600 & - & 0.008 & 0.172 & 0.094 & 0.074 & 0.178 & 0.177 \\
Altai Mtns. & 3700 & 3500 & - & 0.172 & 0.084 & 0.074 & 0.178 & 0.177 \\
Sakhalin & 6200 & 6200 & 4400 & - & 0.088 & 0.173 & 0.235 & 0.262 \\
Japan & 7100 & 7100 & 4300 & 800 & - & 0.127 & 0.209 & 0.207 \\
Dagestan & 2100 & 1700 & 3500 & 7300 & 7700 & - & 0.150 & 0.140 \\
Central China & 6500 & 5800 & 2500 & 3300 & 3100 & 6300 & - & 0.024 \\
Inner Mongolia & 5600 & 5000 & 2300 & 2700 & 2900 & 5700 & 1000 & - \\
\hline
\end{tabular}

Numbers above the diagonal are Tamura (1992) genetic distances. Numbers below the diagonal are geographical distances $(\mathrm{km})$.

Abbreviations: St. P., St. Petersburg.

and maximum parsimony analyses (Fig. 1). Further, maximum likelihood suggested the same relationships, except that the positions of I. ricinus and I. pacificus were reversed. Thus, several major features of the phylogeny were well supported. First, all I. persulcatus populations clustered on the same major branch and in 
isolation from other species. Second, the I. affinis sequence most resembled the inferred ancestral I. ricinus complex sequence. Third, both forms of the I. scapularis sequence shared more recent ancestry with each other than either did with any other sequence.

On average, sequences of species of branch B of Fig. 1 (I. scapularis, I. pacificus, I. ricinus, I. woodi) matched at $93 \%$ of their bases. The alignment of the I. woodi sequence (branch $\mathrm{C}$ of Fig. 1) with branch $\mathrm{B}$ species sequences yielded an average level of sequence identity of $83 \%$. However, when I. persulcatus sequences were aligned with those of $I$. woodi or branch B Ixodes species, they matched at only $68 \%$ and $67 \%$ of their bases, respectively.

\section{Nature of interspecific variation}

Base substitutions $(N=112)$ were more common than indels $(N=64)$ among mutations accounting for interspecific sequence variation (Table 2$)$. As with intraspecific variation in $I$. persulcatus, transitions $(N=50)$ were less common than transversions $(N=62)$ but here the difference was not significant $\left(\chi_{1}^{2}=1.29, P=0.173\right)$. Indels of one to two bases were 2.2 times as common as those of three or more bases.

There was no difference in the relative numbers of indels and base substitutions depending on whether sequence variation was within or between species $\left(\chi_{1}^{2}=1.03, P=0.311\right)$. Also, the number of transitions to transversions did not vary as a function of the source of sequence variation $\left(\chi_{1}^{2}=1.41, P=0.235\right)$. The length of indels for within-species variation, which was dominated by $I$. persulcatus, was less than for betweenspecies variation (Mann-Whitney $U=1700.50$, d.f. $=1$, $P=0.011$; Table 2).

A number of indels characterized differences between I. persulcatus and all other Ixodes species. Sixteen gaps were shared among $I$. persulcatus sequences relative to their alignment with branch B Ixodes species (see Fig. 1). Gaps suggested deletions of $1-18$ bp that encompassed a total of $56 \mathrm{bp}$. Relative to I. persulcatus, branch B species (I. pacificus, I. ricinus, I. scapularis and I. woodi) shared only three alignment gaps of 2-4 bases. These gaps encompassed a total of $10 \mathrm{bp}$. Thus, I. persulcatus sequences were on average 46 bp shorter than those of other Ixodes species.

\section{Discussion}

\section{Population structure}

D3 sequences did not vary geographically in I. pacificus or I. ricinus. These observations are likely to be a consequence of both (1) shallow (weak) population structure and (2) the limited resolution of D3 sequence variation in the assessment of intraspecific variation. For instance, mtDNA sequences revealed haplotype diversity within populations across the range of I. pacificus from British Columbia to the south-western U.S. (Kain et al., 1999). However, the diversity exhibits no geographical pattern or structuring, except that samples of an isolated Utah population differed significantly from other localities (Kain et al., 1999). Perhaps inclusion of additional sites for I. pacificus, such as from Utah, would have revealed some intraspecific variation in the $D 3$ sequence. Variation in rDNA ITS 2 sequences also suggest only weak population structure for I. pacificus but, again, only a few sites were sampled (McLain et al., 1995a). Weak geographical structuring (Kain et al., 1999) is probably a reflection of host vagility. I. pacificus larvae, nymphs and adults parasitize over 80 species of reptiles, mammals and birds (Lane et al., 1991).

The lack of deep structure in I. ricinus may also be explained by the vagility of its hosts. I. ricinus infests over 20 species of passerine birds, some with migratory routes that link southern and northern Europe (Mehl et al., 1984). Some bird hosts show no geographical structuring of their breeding populations across northern and western Europe, consistent with long-range dispersal and geologically recent colonization (see Bensch \& Hasselquist, 1999). Dispersal of I. ricinus ticks across Europe by birds could underpin the gene flow necessary to account for the observed absence of population structure. Also, much of the current range of I. ricinus was glaciated during the most recent Pleistocene ice ages (see Jaarola et al., 1999). Recent range expansion of I. ricinus northward from southern peninsular refugia appears, as is the case with much of the European biota, to be associated with a low degree of genetic diversity and concomitant absence of deep genetic structuring (Hewitt, 1999).

Geographical structuring was indicated for I. scapularis. The range includes much of North America east of the Mississippi River. Here, a southeastern population is indicated by the presence of a $D 3$ sequence variant not observed in the northeastern or midwestern parts of the range. This observation is consistent with the presence of two major clades that have been posited on the basis of variation in mitochondrial $12 \mathrm{~S}$ and $16 \mathrm{~S}$ rDNA sequences (Rich et al., 1995; Norris et al., 1996). Analysis of rDNA ITS 1 sequences (McLain et al., 1995b) and mtDNA cytochrome b SSCPs (Mixon, 1999) also suggests similar genetic differentiation in I. scapularis.

Unfortunately, the present analysis does not identify the nature of sequence variation in $I$. scapularis. The different $D 3$ sequences may co-occur in tandem arrays of rDNA repeating units. Or haploid genomes may be 
homogeneous for either variant. In this case, some populations contain an admixture of such genomes but in different proportions. The latter alternative is consistent with hybridization between members of northern and southern clades (see Hutcheson et al., 1995). Hybridization could be a consequence of range expansions over the last 50 years (Wilson, 1996). Uniformity of haploid genomes is also consistent with high rates of homogenization within and between rDNA arrays (Schloetterer \& Tautz, 1994; see below). For instance, the absence of within-population variation in I. persulcatus, in spite of substantial between-population variation, suggests that repeats within an array share common ancestry more recently than do ticks from different populations.

Monophyly of I. persulcatus populations is strongly supported (Fig. 1) and revealed in shared deletions of approximately 60 bases. Yet, I. persulcatus from different localities exhibit as much sequence variation in the D3 as is observed between all other Ixodes species. Thus, population structure is deep.

Geographical proximity explains some of the genetic structure observed in I. persulcatus. For instance, sequences from nearby localities in western Russia were identical. Relative geographical proximity is also associated with sequence similarity between China and Inner Mongolia and between Sakhalin and Japan. These associations suggest genetic cohesion by way of hostmediated gene flow. Yet, sequences from the Altai Mountains were almost identical to those from western Russia ( $\geq 3500 \mathrm{~km}$ apart). This probably reflects the dispersal and population structure of hosts. For instance, lemmings show no population structure throughout their postglacial range that encompasses arctic Eurasia (Federov et al., 1999).

Deep structure in I. persulcatus may reflect the past presence of multiple refugia from glaciers (including central China as a refuge). Independent evolution of sequences may have occurred within individual refugia before recolonization of the postglacial range (see Hewitt, 1999).

\section{Hosts and dispersal}

Host specificity varies among species of ticks (Hoogstraal \& Aeschlimann, 1982). However, all four of the I. ricinus complex species parasitize various species of reptiles, mammals and birds (James \& Oliver, 1990; Lane et al., 1991). Reptiles generally exhibit moderate to deep genetic structure across small spatial scales due to limited dispersal and habitat discontinuity (e.g. Prosser et al., 1999). Among mammals, bats and rodents are common hosts of some ticks (Hoogstraal \& Aeschlimann, 1982). Bats have deeply structured populations (e.g. Wilmer et al., 1999) whereas rodents do not (e.g. Fedorov et al., 1999). The genetic structure of birds varies among species (Haig et al., 1997) but frequently reveals high rates of gene flow and long-range dispersal (e.g. Da Silva \& Granadeiro, 1999). Thus, birds appear to offer the greatest potential for the long-range dispersal of ticks that would reduce genetic structuring across the range. Birds are frequent hosts of I. pacificus (Lane et al., 1991), I. persulcatus (Anastos, 1957), I. ricinus (Mehl et al., 1984), and I. scapularis (Klich et al., 1996).

\section{Concerted evolution}

A general feature of rDNA sequences is that variation within species is reduced or absent even when interspecific variation is abundant (Hillis \& Dixon, 1991). This represents the homogenization of the multigene family for a particular sequence variant (Dover, 1982). Homogenization is generally believed to result from unequal exchange (Schloetterer \& Tautz, 1994) and biased gene conversion (Hillis et al., 1991) and may occur at different rates for different regions of the rDNA repeating unit (Linares et al., 1994; Polanco et al., 1998).

Concerted evolution is the non-independent evolution of copies of a repeated sequence that results from homogenization (Arnheim, 1983). Concerted evolution of rDNA is rapid (Polanco et al., 1998) which reduces allelic variation within demes and among localities united by gene flow (see Schloetterer \& Tautz, 1994).

Our data suggest that D3 sequences are rapidly homogenized, which would leave little evidence of within-population variation. Our results also suggest that $D 3$ sequences have been homogenized repeatedly. This would lead to the accumulation of interspecific variation with the same kinds of mutations that characterize within-species variation. Sequence identity among the observed I. ricinus complex species is $60 \%$ when $I$. persulcatus is excluded and only $12 \%$ when I. persulcatus is included. Thus, high rates of mutation and recurring episodes of homogenization have captured both the evolutionary independence of these species in highly characteristic sequences and the general evolutionary non-independence of populations composing each species.

\section{Acknowledgements}

The authors thank the persons listed in Table 1. We also thank Tonya Mixon and Quentin Fang for help with sequence alignment and phylogenetic analysis. This work was supported by National Institutes of Health Grant 1R15 AI 34136-01 to D.K.M. 


\section{References}

ADEYeye, O. A. AND BUtLeR, J. F. 1989. Population structure and seasonal inter-burrow movement of Ornithodoros turicata (Acari: Argasidae). J. Med. Entomol., 26, 279-285.

ANASTOS, G. 1957. The Ticks or Ixodides of the USSR. A Review of the Literature. Public Health Service Publ. 548, U.S. Dept. Health and Welfare.

ARNHEIM, N. 1983. The concerted evolution of multigene families. In: Nei, M. and Koehn, R. K. (eds) Evolution of Genes and Proteins, pp. 38-61. Sinauer, Sunderland, MA.

BENSCH, S. AND HASSElQUIST, D. 1999. Phylogeographic population structure of great reed warblers: an analysis of mtDNA control region sequences. Biol. J. Linn. Soc., 66, 171-185.

BULL, C. M., ANDREWS, R. H. AND ADAMS, M. 1984. Patterns of genetic variation in a group of parasites, the Australian reptile ticks. Heredity, 53, 509-592.

DA SILVA, M. C. AND GRANADEIRO, J. P. 1999. Genetic variability and isolation of Cory's shear water colonies in the Northeast Atlantic. Condor, 101, 174-179.

DENNIS, D. T., NEKOMOTO, T. S., VICTOR, J. C., PAUL, W. S. AND PIESMAN, J. 1998. Reported distribution of Ixodes scapularis and Ixodes pacificus (Acari: Ixodidae) in the United States. J. Med. Entomol., 35, 629-638.

DOVER, G. A. 1982. Molecular drive: a cohesive mode of species evolution. Nature, 299, 111-117.

FEDEROV, V., GOROPASHNAYA, A., JARRELL, G. H. AND FREDGA, K. 1999. Phylogeographic structure and mitochondrial DNA variation in true lemmings (Lemmus) from the Eurasian arctic. Biol. J. Linn. Soc., 66, 357-371.

HAIG, S. M., GRATTO-TREVOR, C. L., MUllins, T. D. AND COLWell, M. A. 1997. Population identification of Western Hemisphere shorebirds throughout the annual cycle. Mol. Ecol., 6, 413-427.

HANCOCK, J. M. AND DOVER, G. A. 1988. Molecular coevolution among cryptically simple expansion segments in eukaryotic 26S/28S rRNA. Mol. Biol. Evol., 5, 377-392.

HANCOCK, J. M., TAUTZ, D. AND DOVER, G. A. 1988. Evolution of the secondary structures and compensatory mutations of the ribosomal RNAs of Drosophila melanogaster. Mol. Biol. Evol., 5, 393-414.

HEWITT, G. M. 1999. Post-glacial recolonization of European biota. Biol. J. Linn. Soc., 68, 87-112.

HILliS, D. M. AND DIXON, M. J. 1991. Ribosomal DNA: molecular evolution and phylogenetic inference. $Q$. Rev. Biol., 66, 411-453.

HILlis, D. M., MORITZ, C., PORTER, C. A. AND BAKER, R. J. 1991. Evidence for biased gene conversion in concerted evolution of ribosomal DNA. Science, 251, 308-310.

hoogstraAl, H. AND AeschlimanN, A. 1982. Tick-host specificity. Bull. Soc. Entomol. Suisse, 55, 5-32.

HUTCHESON, H. J., OLIVER, J. H. JR, HOUCK, M. A. AND STRAUSS, R. E. 1995. Multivariate morphometric discrimination of nymphal and adult forms of the blacklegged tick (Acari: Ixodidae), a principal vector of the agent of Lyme Disease in eastern North America. J. Med. Entomol., 32, 827-842.
JAAROLA, M., TEGELSTROEM, H. AND FREDGA, K. 1999. Colonization history in Fennoscandian rodents. Biol. J. Linn. Soc., 68, 113-127.

JAMES, A. M. AND OLIVER, J. H. JR. 1990. Feeding and host preference of immature Ixodes dammini, I. scapularis, and I. pacificus (Acari: Ixodidae). J. Med. Entomol., 27, 324-330.

KAIN, D. E., SPERLING, F. A. H., DALY, H. V. AND LANE, R. S. 1999. Mitochondrial DNA sequence variation in Ixodes pacificus (Acari: Ixodidae). Heredity, 83, 378-386.

KLICH, M., LANKeSTER, M. W. AND WU, K. W. 1996. Spring migratory birds (Aves) extend the northern occurrence of the blacklegged tick (Acari: Ixodidae). J. Med. Entomol., 33, 581-585.

KUZOFF, R. K., SWERE, J. A., SOLTIS, D. E. AND ZIMMER, E. A. 1998. The phylogenetic potential of the entire 26S rDNA sequences in plants. Mol. Biol. Evol., 15, 251-263.

LAMPO, M., RANGEL, Y. AND MATA, A. 1998. Population genetic structure of a three-host tick, Amblyomma dissimile, in eastern Venezuela. J. Parasitol., 84, 1137-1142.

LANE, R. S., PIESMAN, J. AND BURGDORFER, w. 1991. Lyme borreliosis: relation of its causative agent to its vectors and hosts in North America and Europe. Ann. Rev. Ent., 36, 587-609.

LINARES, A. R., BOWEN, T. AND DOVER, G. A. 1994. Aspects of nonrandom turnover in the concerted evolution of intergenic spacers within the ribosomal DNA of Drosophila melanogaster. J. Mol. Evol., 39, 151-159.

LitVAitis, M. K., NUNN, G., THOMAS, W. K. AND KOCHER, T. D. 1994. A molecular approach for the identification of meiofaunal turbellarians (Platyhelminthes, Turbellaria). Mar. Biol., 120, 437-422.

LIVAK, K. 1984. Organization and mapping of a sequence on the Drosophila melanogaster $\mathrm{X}$ and $\mathrm{Y}$ chromosomes that is transcribed during spermatogenesis. Genetics, 107, 611-634.

MCLAIN, D. K., WESSON, D. M., COLLINS, F. H. AND OLIVER, J. H. JR. 1995a. Evolution of the rDNA spacer, ITS 2, in the ticks Ixodes scapularis and I. pacificus (Acari: Ixodidae). Heredity, 75, 303-319.

MCLAIN, D. K., WESSON, D. M., OLIVER, J. H. JR AND COLLINS, F. H. 1995b. Variation in ribosomal DNA internal transcribed spacers 1 among eastern populations of Ixodes scapularis (Acari: Ixodidae). J. Med. Entomol., 32, 353-360.

MEHL, R., MICHAELSEN, J. AND GUNNAR, L. 1984. Ticks (Acari, Ixodides) on migratory birds in Norway. Fauna Norv. Ser. B., 31, 46-58.

MIXON, T. R. 1999. Genetic Variation in the Tick Ixodes scapularis Detected Using SSCP. MSc Thesis, Georgia Southern University.

MULVEY, M., AHO, J. M., LYDEARD, C., LEBERG, P. L. ET AL. 1991. Comparative population genetic structure of a parasite (Fascioloides magna) and its definitive host. Evolution, 45, 1628-1640.

NORRIS, D. E., KLOMPEN, J. S. H., KEIRANS, J. E., BLACK, W. C., IV. 1996. Population genetics of Ixodes scapularis (Acari: Ixodidae) based on mitochondrial $16 \mathrm{~S}$ and $12 \mathrm{~S}$ genes. J. Med. Entomol., 33, 78-89.

OLIVER, J. H. JR, KEIRANS, J. E., LAVENDER, D. R. AND HUTCHESON, H. J. 1987. Ixodes affinis Neuman (Acari: Ixodidae): new host and distribution records, description of immatures, seasonal 
activities in Georgia, and laboratory rearing. J. Parasitol., 73, 646-652.

POlANCO, C., GONZAlez, A. I., FUENTE, A. AND DOVER, G. A. 1998. Multigene family of ribosomal DNA in Drosophila melanogaster reveals contrasting patterns of homogenization for IGS and its spacer regions: a possible mechanism to resolve this paradox. Genetics, 149, 243-256.

PROSSER, M. R., GIBBS, H. L. AND WEATHERHEAD, P. J. 1999. Microgeographic population structure in the northern water snake, Nerodia sipedon sipedon detected using microsatellite DNA loci. Mol. Ecol., 8, 329-333.

RICH, S. M., CAPORALE, D. A., TELFORD, S. R., III, KOCHER, T. D., HARTL, D. L. AND SPEILMAN, A. 1995. Distribution of the Ixodes ricinus-like ticks of eastern North America. Proc. Natl. Acad. Sci. U.S.A., 92, 6284-6288.

ROBBINS, R. G. AND KEIRANS, J. E. 1992. Systematics and ecology of the subgenus Ixodiopsis (Acari: Ixodidae: Ixodes). Thomas Say Foundation Monogr. 14.

SAITOU, N. AND NEI, M. 1987. The neighbor-joining method for reconstructing phylogenetic trees. Mol. Biol. Evol., 4, 406-425.

SAMBROOK, J., FRITSCH, E. F. AND MANIATIS, T. 1989. Molecular Cloning: a Laboratory Manual. Cold Spring Harbor, NY.

SCHLOETTERER, C. AND TAUTZ, D. 1994. Chromosomal homogeneity of Drosophila ribosomal arrays suggests intrachromosomal exchanges drive concerted evolution. Curr. Biol., 4, $777-783$.
SLATKIN, M. 1987. Gene flow and the geographic structure of natural populations. Science, 236, 787-792.

SMITH, S. W., OVERBEEK, R., WOESE, C. R., GILBERT, W. AND GILlVET, P. M. 1994. The genetic data environment and expandable GUI for multiple sequence analysis. CABIOS, 10, 671-675.

SWOFFORD, D. L. 2000. PAUP: phylogenetic analysis using parsimony (and other methods). Version 4. Sinauer Assoc., Sunderland, M.A.

TAMURA, K. 1992. Estimation of the number of nucleotide substitutions when there are strong transition-transversion and G+C-content biases. Mol. Biol. Evol., 9, 678-687.

TAUTZ, D., HANCOCK, J. M., WEBB, D. A., TAUTZ, C. ET $A L .1988$. Complete sequences of the rRNA genes of Drosophila melanogaster. Mol. Biol. Evol., 5, 366-376.

THOMPSON, J. D. 1999. Population differentiation in Mediterranean plants: insights into colonization history and the evolution and conservation of endemic species. Heredity, 82, 229-236.

WILMER, J. W., HALl, L., BARRATT, E. AND MORITZ, C. 1999. Genetic structure and male-mediated gene flow in the ghost bat (Macroderma gigas). Evolution, 53, 1582-1591.

WILSON, M. L. 1996. Distribution and abundance of Ixodes scapularis (Acari: Ixodidae) in North America: ecological processes and spatial analysis. J. Med. Entomol., 35, 446-457. 